\title{
Control of Parthenium hysterophorus L. and its Impact on Yield Performance of Tomato (Solanum lycopersicum L.) in the Northern Province of Sri Lanka
}

\author{
K. Nishanthan, S. Sivachandiran ${ }^{1}$ and B. Marambe ${ }^{2 *}$ \\ Postgraduate Institute of Agriculture \\ University of Peradeniya \\ Sri Lanka
}

\begin{abstract}
Impact of weed control methods on the persistence of $\underline{\text { Parthenium }}$ hysterophorus L., and tomato (Solanum lycopersicum L.) yield was studied in two farmer fields i.e. a site heavily infested with $\underline{P}$. hysterophorus (Parthenium-site) and Partheniumfree site, in the Jaffna peninsula of the Northern Province of Sri Lanka. The split-plot design consisted of two main plots i.e. manual weeding and ploughing (both followed by harrowing), and three sub-plots i.e. use of a pre-emergent herbicide (Oxyfluorfen; $240 \mathrm{~g} / \mathrm{L}$ EC at 2 days before planting), mulching [Gliricidia sepium (Jacq.) Kunth ex Walp. leaves at $12 \mathrm{~kg}$ per plot on fresh weight basis], and un-weeded plot after crop establishment (control), in three replicates. The soil seed bank of the Parthenium-site was dominated by $\underline{P}$. hysterophorus as expected, and the Parthenium-free site was dominated by the perennial sedge Cyperus rotundus $L$. At tomato harvest, the un-weeded sub-plots recorded the highest weed densities $(p<0.05)$ when compared to the rest, The Parthenium-site showed a higher weed dry weight $(p<0.05)$ when compared to that of the Parthenium-free site, due to higher emergence of the Parthenium weed in the former. Mulching was the best sub-plot treatment for Parthenium control in combination with the main plot treatments. The average fruit weight of tomato at the Parthenium-free site was $7.8 \%$ higher than that of the Partheniumsite (47.8 g per fruit). In the Parthenium-site, mulching resulted in a $6.4 \%$ higher fruit weight and $58 \%$ higher total yield $(p<0.05)$ when compared to the rest of the sub-plot treatments. The weed competition negatively affected the tomato yield $\left(Y=-0.7551 X+7.88 ; R^{2}=0.58\right.$; $p<0.05)$, with Parthenium weed playing a dominant role. Mulching with $\underline{G}$. sepium coupled with manual weeding during land preparation or ploughing would suppress growth and development of weeds including $\underline{P}$. hysterophorus and enhance yield of tomato.
\end{abstract}

Keywords: Parthenium hysterophorus, Solanum lycopersicum, weed competition, weed control, tomato yield

\section{INTRODUCTION}

Parthenium hysterophorus L. of family Asteraceae is an invasive alien plant species at global level. The Parthenium weed, also known as White Top or Congress Weed, has been speculated to have entered Sri Lanka in 1987 with the Indian Peace Keeping Force (Jayasuriya, 1999). Parthenium has concurrently or subsequently entered Sri Lanka with

\footnotetext{
Department of Agronomy, Faculty of Agriculture, University of Jaffna, Sri Lanka

Department of Crop Science, Faculty of Agriculture, University of Peradeniya, Sri Lanka

Corresponding author: bmarambe@pdn.ac.lk
} 
chilli and onion seeds contaminated with weed seeds imported from India (Marambe et al., 2001). It contains special characters such as high germination ability, large seed production capacities, high survival rate, extreme adaptability in different habitats, easy dispersal of seeds, high allelopathic impact and can complete life cycles within four weeks (http://www.gits4u. com/agri/agri8.htm).

Tomato (Solanum lycopersicum L.) of the family Solanaceae is a major vegetable crop of economic importance in the emerging economy of the Northern Province of Sri Lanka, which accounts for $16.2 \%$ of the cultivated extent of vegetables in the province (Anonymous, 2012). Weed management is one of the critical crop management concerns of farmers who aim at increasing crop productivity. Marambe \& Sangakkara (1997) reported significant reductions in tomato growth, development and yield due to weed competition, and Marambe et al. (2002) also reported of a fruit yield reduction in tomato by $72 \%$ and in chilli by $27 \%$ due to infestation with Cuscuta spp. Seneviratne et al. (1984) reported that the weed Acanthospermum hispidum DC. has a negative impact on growth and yield of tomato. The Department of Agriculture identifies weed control as a key management practice for higher yields of tomato (http://www.agridept.gov.lk/index.php/en/crop-recommendations /988).

Parthenium has been identified as an invasive alien plant in Sri Lanka, after a post-entry risk assessment (Ranwala et al., 2011). The plant has also been listed in the "Weeds of National Significance (WONS)" by the Sri Lanka Council for Agricultural Research Policy (SLCARP) in its National Weed Strategy for 2009-2014 (Rajapakse et al., 2012) and National Priorities in Plant Protection Research 2011-2013 (Marambe et al., 2011) thus, indicating the highest level recognition received by this invasive alien plant to design appropriate management practices. Parthenium has emerged as a major biotic constraint to the vegetable growing farmers in the Northern Province of Sri Lanka resulting in extra effort on time and financial investment in order to ensure favourable growing conditions to the vegetable crops to reap greater harvests. Studies have reported that the growth toxins released to the soil through leaching and decaying of the plant parts of Parthenium inhibit branching and yield in tomato (Kanchan, 1975). Parthenium has also been found to be the secondary host of tomato leaf curl virus (Govindappa et al., 2005), and to suppress local vegetation by release of growth inhibitors through leaching, exudation of roots, decay of roots, decay of residues, etc. (Sukhada \& Jayachandra, 1979). Shabbir \& Bajwa (2006) reported that the rapid decline in populations of many common medicinal plants growing in the wastelands of Islamabad, Pakistan could be due to the aggressive colonization by Parthenium. The weed was also reported to cause up to $40 \%$ yield loss in various crops and also affect animal and human health (Gnanav et al., 2013), and cause socio economic impacts such as reducing the economic returns to the farmers, reduction of crop yield and quality of harvest, increased cost of production, affecting the cropping system, reducing crop diversification and reducing the value of crop lands, depreciating the value of pasture, grains, and hay due to contamination thus reducing market options.

The total extent of invasion by Parthenium in the Jaffna peninsula has been estimated as 137,225 ha (Anonymous, 2010). This invasive alien plant has been reported to have affected the lands cultivated with vegetable crops such as tomato in the Northern Province of the country thus warranting its control. The SLACRP, in its national plant protection research priorities, recommends the development of weed management strategies for Parthenium in vegetable crops. Thus, the knowledge on the level of impact of Parthenium on major vegetable crops would be imperative to design judicious control strategies of this invasive alien species. However, there is a scarcity of information on the quantitative and qualitative impact of Parthenium on vegetable crops such as tomato grown in Sri Lanka and the 
response of the weed to different weed control techniques, especially in weed emergence. Considering the national need, this study was thus designed to study the soil seed bank of Parthenium, evaluate different weed control methods of Parthenium on the growth and yield of tomato in farmer fields in the Northern Province of Sri Lanka.

\section{MATERIALS AND METHODS}

Two experimental sites were selected in the Jaffna district of the Northern Province of Sri Lanka in the agro-ecological region of $\mathrm{DL}_{3}$, with one site infested with the weed $P$. hysterophorus L. (Parthenium-site) and the other a Parthenium-free site. The Parthenium-site was selected after a careful screening of sites having a uniform thicket of Parthenium plants. The tomato (Solanum lycopersicum L.) variety $\mathrm{KC}_{1}$ was selected for the experiment due to the suitability of the variety for both Yala and Maha seasons in the dry zone of Sri Lanka, heat tolerance and high yield (40 mt/ha). The experiment was conducted in the Maha season $2012 / 2013$ in a split plot design with three replicates. In both sites, the two main plots (17.1 $\mathrm{m} \times 6 \mathrm{~m}$ ) were established to apply the conventional weed removal techniques, i.e. manual removal and ploughing weed to the soil. Both techniques were followed by harrowing to loosen the soil to prepare a good seed bed for tomato as done by the farming community.

Each main plot was further divided into three sub plots each at the size of $2 \mathrm{~m} \times 2.4 \mathrm{~m}$ to apply the pre-emergent herbicide Oxufluorfen $\left(\mathrm{Goal}^{\circledR} 240 \mathrm{~g} / \mathrm{L} \mathrm{EC}\right.$ at $0.75 \mathrm{~L} / \mathrm{ha}$ using a knapsack sprayer fitted with a double-cone nozzle having a delivery rate of $355 \mathrm{~mL} / \mathrm{min}$ and a spray volume of $375 \mathrm{~L} / \mathrm{ha}$ ) at 2 days before transplanting tomato, and leaf mulch of Gliricidia sepium (Jacq) Kunth ex Walp (12 kg per plot on fresh weight basis, soon after transplanting), and to maintain an un-weeded plot as the control. No post-plant herbicides were used in this study due to the risk of phytotoxicity and contamination of tomato plants. Twenty one days old tomato seedlings grown in nurseries were transplanted at a spacing of $80 \mathrm{~cm}$ x $50 \mathrm{~cm}$. After transplanting, all the weeds except Parthenium were manually removed at biweekly intervals until harvest in the "Parthenium-site", and all weeds were manually removed at same time intervals in the Parthenium-free site. All other management practices were carried out according to the recommendations of the Department of Agriculture (http://www. agridept.gov.lk/index.php/en/crop-recommendations/988).

Soil properties such as soil $\mathrm{pH}$ (1:5 soil:distilled water; using a $\mathrm{pH}$ meter), soil temperature (daily records using a soil thermometer), soil Nitrogen (initial total nitrogen content using Kjeldahl method), phosphorous (Olsen method) and potassium (flame photometric method) were estimated (Anonymous, 1970) prior to commencement of the experiment. In order to study the initial soil seed bank, soil samples were collected from three random locations in the main plots using an auger at $0-5 \mathrm{~cm}, 5-10 \mathrm{~cm}$ and $10-15 \mathrm{~cm}$ depths. Within each main plot, 10 samples were collected at respective depths, the composite samples at each depth were spread on plastic trays, and the soil seed bank was allowed to germinate for 2 weeks at room temperature where the soils were moistened throughout the experiment. The number of weeds per unit area of the sample was recorded. After establishment of tomato seedlings, the composition of weed flora (species-wise count) in Parthenium-site and Parthenium-free site were estimated by collecting three random samples per main plot at bi-weekly intervals using a $1 \mathrm{~m} \times 1 \mathrm{~m}$ quadrat. The weed biomass was measured using destructive samples (one sample per plot using a quadrat of $50 \mathrm{~cm} \times 50 \mathrm{~cm}$ ) at the time of harvest. The weed dry weight was taken by oven drying the samples at $65^{\circ} \mathrm{C}$ until a constant weight. 
Tomato was harvested in 6-7 picks over four weeks in both experimental sites. The yield components of tomato namely, the percentage fruit set, number of fruits per plant, fruit weight and the total yield per plant were measured. The yield components were measured using six randomly selected plants per sub plot. The ANOVA was performed using the GLM procedure of the SAS computer software package.

\section{RESULTS AND DISCUSSION}

At the Parthenium-site, the soil total nitrogen content varied from 1.0-38 mg/100 g soil, the phosphorus content varied from $970-1980 \mathrm{mg} / 100 \mathrm{~g}$ soil, and the potassium content varied from $16-46 \mathrm{mg} / 100 \mathrm{~g}$ soil. In the Parthenium-free site the soil total nitrogen content varied from 1.0-31.2 mg/100 g soil, phosphorous content varied from 820-1910 mg/100 g soil, and potassium content varied from $16-38 \mathrm{mg} / 100 \mathrm{~g}$ soil. The soil temperature in the Parthenium site was $20.5-24.5^{\circ} \mathrm{C}$ and in the Parthenium-free site was $20.5-23.5^{\circ} \mathrm{C}$. The soil $\mathrm{pH}$ of both sites varied between 7.2-7.3.

\section{Composition of weed flora}

The initial weed counts indicated that the Parthenium-free site was dominated by the perennial sedge Cyperus rotundus L. and the dominant broad leaf in the Parthenium-site, as anticipated, was P. hysterophorus. Cyperus rotundus has a higher ability to regenerate through the network of rhizomes and tubers (Marambe, 1996) and Parthenium may have developed its competitive ability to dominate fields through its allelopathic effect (Navie et al., 1994; Evans, 1997; Belzetal., 2007).

Among the other weed species present in the Parthenium-free experimental site, the dominant grasses were Panicum repens L. and Isachne globosa Thunb., and the dominant broadleaf weeds were Amaranthus hybridus L. and Tridax procumbens L. In the Partheniumsite, $C$. rotundus was the dominant sedge, Cynodon dactylon L. Pers. was the dominant grass species and Amaranthus viridis L. and Trianthema portulacastrum L. were the other broadleaf weeds present apart from Parthenium.

\section{Soil seed bank of weeds}

In the Parthenium-site, the viable seed population of Parthenium was the highest at the upper soil layers (soil depth $<5 \mathrm{~cm}$ ) and the seed bank declined with increasing soil depth (Table $1)$. The results are in agreement with the previous studies where the seedlings of Parthenium emerged from shallow buried $(<0.5 \mathrm{~cm})$ seeds due to the exhaustion of seedling reserves before emergence or induced dormancy (Tamado et al., 2002). Similar results were observed in the case of grasses and sedges as well. In the Parthenium-free site, the sedges were dominant in the soil seed bank (Table 2). 
Table 1. Distribution of soil seed bank of Sedges and grasses in the Parthenium-study site

\begin{tabular}{cccc}
\hline $\begin{array}{c}\text { Soil } \\
\text { depth } \\
(\mathrm{cm})\end{array}$ & $\begin{array}{c}\text { No. of viable Parthenium } \\
\text { seeds } \\
\text { (per sq meter) }\end{array}$ & $\begin{array}{c}\text { No. of viable sedge } \\
\text { seeds } \\
\text { (per sq meter) }\end{array}$ & $\begin{array}{c}\text { No. of viable grass } \\
\text { seeds } \\
\text { (per sq meter) }\end{array}$ \\
\hline $0-5$ & $22 \pm 4$ & $5 \pm 1$ & $3 \pm 1$ \\
$5-10$ & $7 \pm 2$ & $4 \pm 1$ & $2 \pm 0$ \\
$10-15$ & $2 \pm 1$ & $1 \pm 0$ & $1 \pm 0$ \\
\hline
\end{tabular}

Values presented as mean \pm standard deviation of three samples per main plot $(n=18)$

Higher weed seed banks observed in the case of Parthenium at the Parthenium-site suggest the aggravated threat that this weed could cause in the future as multiple dormancy mechanisms in buried Parthenium seeds were reported to enhance their persistence in the environment (Navie et al., 1998).

Table 2. Distribution of soil seed bank in the Parthenium free-study site

\begin{tabular}{cccc}
\hline $\begin{array}{c}\text { Soil } \\
\text { depth } \\
(\mathrm{cm})\end{array}$ & $\begin{array}{c}\text { No. of viable broad leaf } \\
\text { seeds } \\
\text { (per sq meter) }\end{array}$ & $\begin{array}{c}\text { No. of viable sedge seeds } \\
\text { (per sq meter) }\end{array}$ & $\begin{array}{c}\text { No. of viable grass } \\
\text { seeds } \\
\text { (per sq meter) }\end{array}$ \\
\hline $0-5$ & $5 \pm 0$ & $27 \pm 1$ & $6 \pm 1$ \\
$5-10$ & $3 \pm 1$ & $18 \pm 3$ & $5 \pm 1$ \\
$10-15$ & $0 \pm 0$ & $7 \pm 1$ & $1 \pm 0$ \\
\hline
\end{tabular}

Values presented as mean \pm standard deviation of three samples per main plot $(n=18)$

\section{Impact of the control methods on weed densities and weed dry weight}

The weed densities, which are a clear indication of the emergence of weed seedlings, found in different sites showed a significant difference $(\mathrm{p}<0.05)$, with the Parthenium-site recording a higher weed density mainly due to the dominance of $P$. hysterophorus. The plots kept unweeded after transplanting tomato (un-weeded control) showed the highest weed densities dominated by $P$. hysterophorus in the Parthenium-site where other broadleaf weeds dominated the Parthenium-free site. Ploughing and manual weed control treatments alone did not show an effective suppression of Parthenium weed, and the impact of these two treatments were non-significant ( $p>0.05$; Fig. 1$)$. 

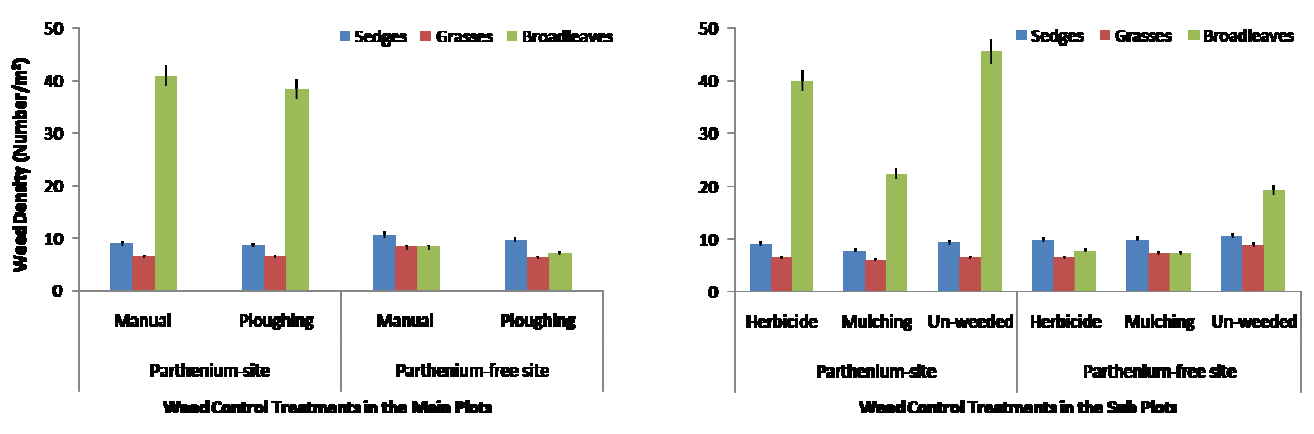

Fig. 1. Impact of main plots and sub plot treatments on the weed densities at 8 weeks after planting tomato in the experimental sites (Note: Almost all the broadleaf weeds found in the Parthenium-site were $P$. hysterophorus). The vertical bars represent standard error of the mean of three replicates per treatment.

Khan et al. (2013) reported that manual weeding and tillage are the most common control practices used to control Parthenium weed, however, the present study indicates that these techniques alone are inadequate to provide a successful control of this invasive alien plant. The results clearly showed that the emergence of other broad leaf weeds together with grasses and sedges in both sites were successfully controlled by ploughing and manual weeding treatments used in this study, especially in the Parthenium-free site (Fig. 1). This has resulted in relatively low weed densities even in the un-weeded control plots. This also indicates that the late emergence of broadleaf weeds was low in the Parthenium-free sites, while the Parthenium weed emerges at different growth stages of the crop, which could be due to various dormancy mechanisms (Navie et al., 1994) and non-synchronous breaking of dormancy in Parthenium seeds found in the soil seed bank resulting in the persistence of this invasive plant.

In the Parthenium-free site, the weed control treatments in the sub-plots resulted in similar effectiveness in emergence of sedges, grasses and broadleaf weeds when compared to the plots kept un-weeded after the tomato crop was established. This confirms that the impact of the main plot treatments was effective and the sub-plot weed control treatments have also been successful in suppressing the emergence of weeds at early growth stages. The preemergent herbicide used in this study was effective in suppressing the emergence of the sedges, grasses and broad leaf weeds, except Parthenium. The sub-plot treatments in both sites showed that mulching suppressed the weed growth effectively $(p<0.05)$ than the other two treatments by reducing light penetration to soil surface while creating a physical pressure on the emerging weeds and thus serving as a barrier for weed growth in both experimental sites. In addition to physical suppression of weeds, the decomposition of plant residues can also release phytotoxic compounds (i.e. allelopathic effects) that inhibit weed growth (Tiang $\&$ Kang, 1994). However, the G. sepium is found to show no negative effects on crop species such as corn and bean (Silva et al., 2009) and tomato (Olasantan, 2000).

Though the mulch suppressed weed growth effectively, some Parthenium plants germinated close to tomato plant, in places where there was insufficient cover from the mulch, resulting in higher weed densities under the broadleaf weed category (Fig. 1). Javaid et al. (2010) reported that the germination rate of the Parthenium weed is negatively affected by environmental temperature and solar radiation intensity. In this study, the temperature of the 
experimental sites decreased gradually from 28 to $24^{\circ} \mathrm{C}$ and solar radiation intensity from 5.08 to $4.57 \mathrm{kwh} / \mathrm{m}^{2} /$ day. This gradual decrease could have contributed to the late emergence and growth of Parthenium weed as observed in this study. Acquuah (2002) reported that natural phytotoxins are released when organic materials such as mulches decompose and this may inhibit the growth of weeds.

The dry weight of weeds at harvesting stage of the tomato crop showed a significant difference $(p<0.05)$ between the two study sites mainly due to the dominance of the $P$. hysterophorus in the Parthenium-site (Fig. 2). The un-weeded control recorded the highest weed densities $(\mathrm{p}<0.05)$ when compared to the weed control treatments suggesting that all sub-plot treatments have had a considerable control not only on the emergence of weeds but on the growth of weeds as well, especially P. hysterophorus.
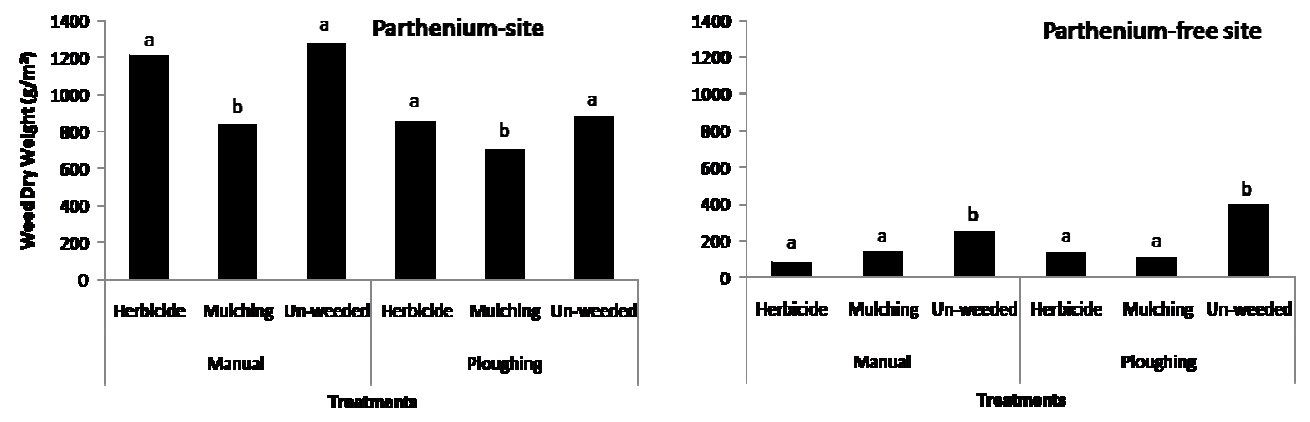

Fig. 2. Effect of different weed control treatments on weed dry weight at the Parthenium-site and Partheium-free site at the time of harvesting of tomato. In each site, within manual weeding and ploughing, the bars with same letter are not significantly different at $\boldsymbol{p}=\mathbf{0 . 0 5}$.

The mulching treatment was the best among the sub-plot weed control treatments, which was followed by two main plot weed control techniques. Olasantan (2000) also reported that Gliricidia mulch could result in 60-66\% weed control in tomato. Marambe \& Sangakkara (1997) also reported that in nature farming, gliricidia leaf mulch alone could reduce the weed population densities by 17-19\%. The differences observed among the sub-plot treatments in weed density (Fig. 1) and weed dry weight (Fig. 2) could be attributed to the occurrences of the weed seedlings at difference growth stages due to difference seedling emergence times as stated previously in this paper.

\section{Impact of different weed control strategies of Parthenium on the quantitative yield of tomato}

The fruit set of tomato in the Parthenium-free site $(44 \%)$ was significantly higher $(p<0.05)$ when compared to that of the Parthenium site (36\%), with no significant differences $(p>0.05)$ observed among the treatments within a site (Fig. 3). However, the number of fruits per tomato plant differed significantly between the two sites and among treatments within a site (Fig. 4). There was no significant interaction $(p>0.05)$ between the main plot (conventional) and sub-plot weed control treatments in both sites 
The average fruit weight in the Parthenium-free site $(51.6 \pm 1.5 \mathrm{~g}$ per fruit) was $7.8 \%$ higher $(p<0.05)$ than that of the Parthenium-site ( $47.8 \mathrm{~g}$ per fruit). In the Parthenium-free site, the fruit weight was not-significantly different $(p>0.05)$ between the sub-plot weed control treatments (data not shown).In the Parthenium-site, the average fruit weight was the lowest in the un-weeded control (44.7 g per fruit) while the mulching treatment recorded an average fruit weight ( $49.8 \mathrm{~g}$ per fruit), which was $6.4 \%$ higher than the rest of the sub-plot treatments $(p<0.05)$.
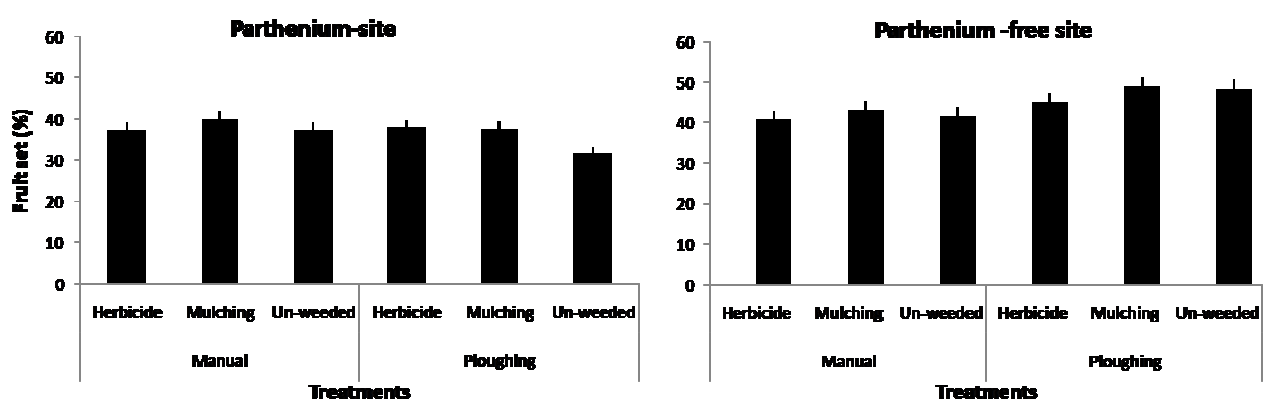

Fig. 3. The percentage fruit set in tomato at Parthenium-site and Parthenium-free site. The vertical bars represent standard error of the mean of six plant per $\operatorname{plot}(\mathbf{n}=18)$.
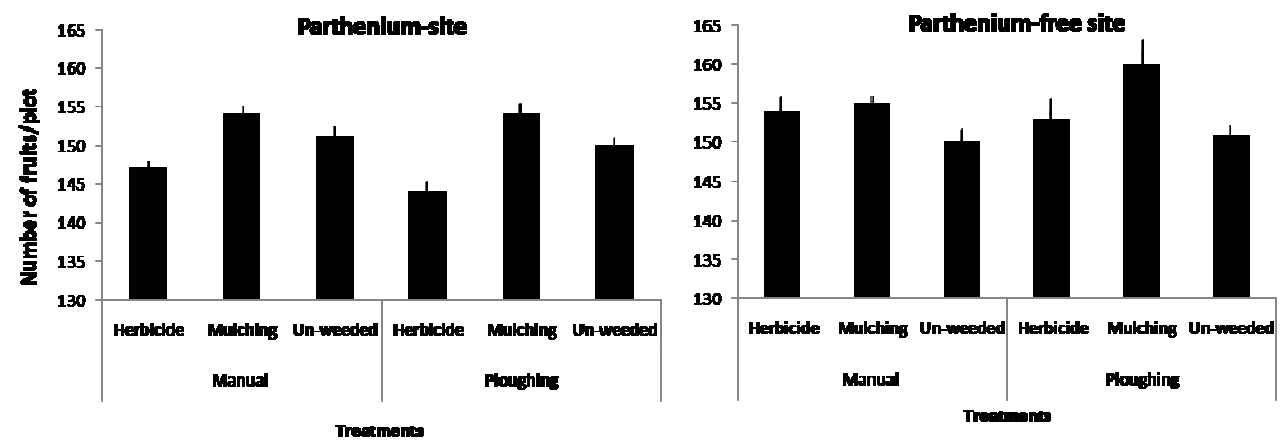

Fig. 4. Number of fruits per tomato plant under different weed control treatments at the Parthenium-site and Parthenium-free site. The vertical bars represent standard error of the mean of six plants per plot $(n=18)$.

Similar to results observed on the average fruit weight of tomato, the mulching treatment in the parthenium-site recorded a pooled final yield of $7.5 \mathrm{t}$ per ha, which was $58 \%$ higher $(p<0.05)$ when compared to that of the other two sub-plot treatments (Fig. 5). 

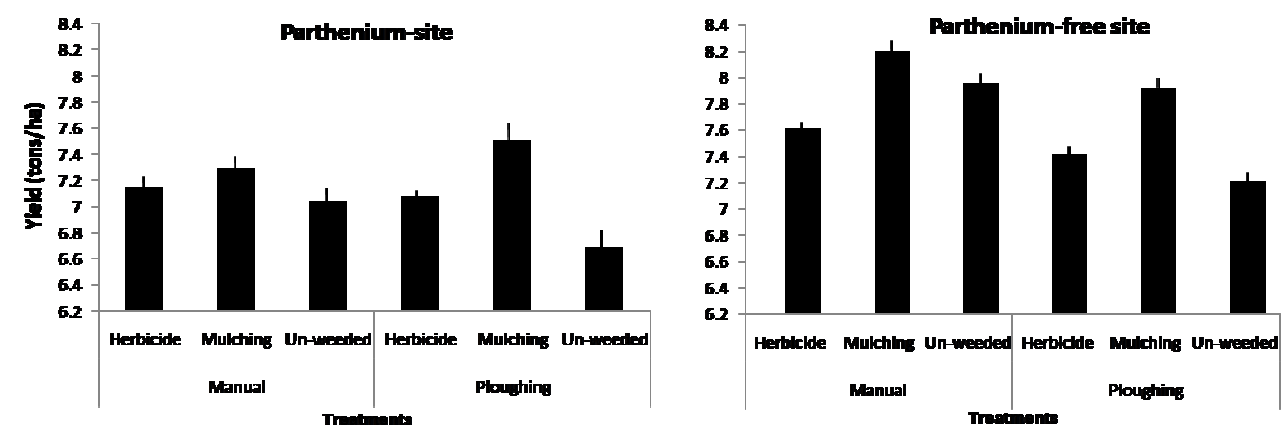

Fig 5. Total yield of tomato under different weed control treatments at the Parthenium-site and Parthenium-free site. The vertical bars represent standard error of the mean of six plants per plot $(n=18)$.

The results are in agreement with the weed control data observed in the present study where the Parthenium-site had a higher weed pressure ( $P$. hysterophorus) when compared to the Parthenium-free site, while the mulching treatment resulted in a significantly higher weed control in both sites. The un-weeded control plots recorded the lowest total yield $(6.7 \mathrm{t}$ per ha) at the Parthenium-site, which was $11 \%$ lower than those recorded in the un-weeded plots in the Parthenium-free site.

Awodoyin et al. (2007) reported that compared to un-weeded control that had the least total fruit yield, different types of mulches could increase the tomato fruit yield by $152-237 \%$ and un-weeded treatment could reduce the fruit yield in tomato by about $65 \%$ compared to pooled average yield of mulching treatments. Figure 6 clearly illustrates the impact of weed competition on the total yield of tomato as observed in this study. Though a detailed analysis of the competitive mechanism between Parthenium weed and tomato crop observed in this study is required, previous results suggest that the pollen of Parthenium has been reported to inhibit the pollen germination and fruit set of the nearby species (Kanchan \& Jayachandra, 1980).

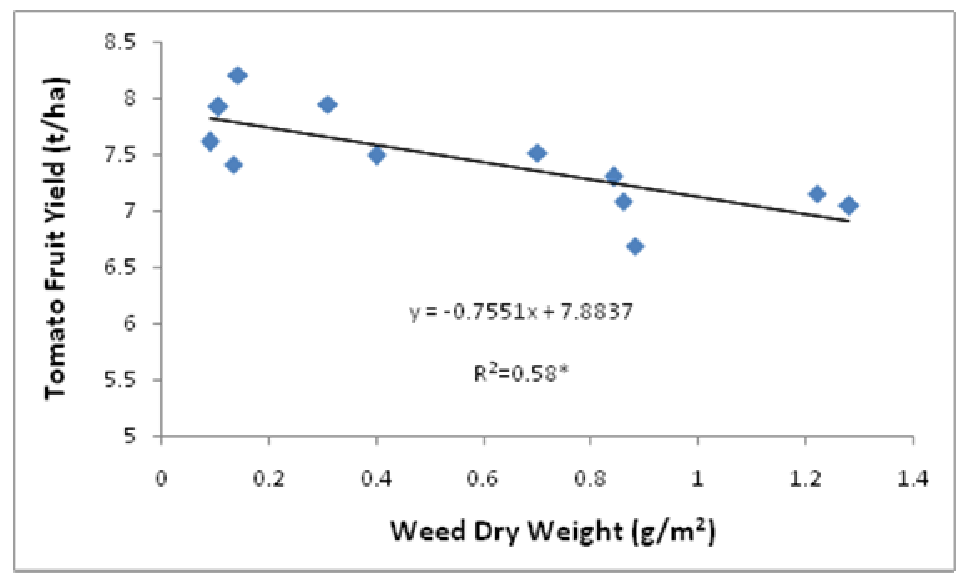

Fig. 6. Regression analysis of the weed dry weight and tomato yield as observed in the study. $R^{2}=0.58(p<0.05)$. 
Towers et al. (1977) also reported that heavy accumulation of pollen of P. hysterophorus on the stigmatic surface caused a $40 \%$ reduction in crop yield and that the weed may still exhibit an inhibitory influence on crops even when grown at a considerable distance. The good fruit yield obtained under mulching in this study confirms earlier report that mulch film improves the performance of tomato compared to no-mulch treatments (Hochmuth et al., 2001; OparaNadi, 1993; Hudu et al. 2002; Awodoyin \& Ogunyemi, 2002). This study confirmed that mulching could successfully suppress the growth of Parthenium in tomato cultivation and hence enhance the growth and yield of the crop when compared to other tested treatments. The increased fruit yield of tomato with mulching could be explained by the conservation of moisture and reduction of temperature in the top of soil, and suppression of weed growth (Ghosh et al. 2006; Awodoyin et al., 2007; Liu et al., 2011). Impact of allelopathic effects of Parthenium on different crops has also been reported as possible causal mechanism for reduction in crop yield (Khosla \& Sobti 1981; Channappagoundar et al., 1990; Evans, 1997).

\section{CONCLUSIONS}

The results indicated that the Parthenium weed dominated in sites, including the soil seed bank, suppressing other weed species confirming its invasive behavior to be identified as one of the major invasive alien plants in Sri Lanka. The weed had a significant negative impact on the tested growth parameters of tomato indicating its competitive ability against the annual crop. Tillage practices alone are not effective in controlling the Parthenium weed. However, a combination of pre-plant and post-plant weed control treatments would be best suited to control this invasive alien plant under crop production systems. The present study indicated that mulching with Gliricidia sepium, or any other suitable and a cost-effective mulch, coupled with manual weeding before land preparation or ploughing would help suppressing the growth and development of the Parthenium weed and enhance yield of tomato.

\section{REFERENCES}

Acquaah, G. (2002). Principles of Crop Production: Theory, Techniques, and Technology. Upper Saddle River, N.J.: Prentice Hall of India Private Limited New Delhi, India.

Anonymous (1970). Official method of analysis of the Association of Official Analytical Chemist. $11^{\text {th }}$ Edition, Washington DC, U.S.A.

Anonymous (2010). Administrative Report. Provincial Department of Agriculture, Northern Province, Sri Lanka.

Anonymous (2012). Administrative Report. Provincial Department of Agriculture, Northern Province, Sri Lanka.

Anthon, G.E. LeStrangeb, M. and Barretta, D.M. (2011). Changes in pH, acids, sugars and other quality parameters during extended vine holding of ripe processing tomatoes. J. Sc. Food Agric. DOI 10.1002/jsfa.4312.

Awodoyin, R.O. and Ogunyemi, S. (2005). Use of sicklepod, Senna obtusifolia (L.) Irwin and Barneby, as mulch interplant in cayenne pepper, Capsicum frutescens L., production. Emirate Journal Agricultural Science .17(1), 10-22. 
Awodoyin, R.O., Ogbeide F.I. and Oluwole O. (2007). Effects of three mulch types on the growth and yield of tomato (Lycopersicon esculentum Mill.) and weed suppression in Ibadan, Rainforest-savanna Transition Zone of Nigeria. Tropical Agricultural Research \& Extension. 10, 53-60.

Belz, R.G., Van der Laan, M., Reinhadt, C. F. and Hurle, K. (2007). Soil degradation of parthenin - does it contradict a role in allelopathy of the invasive weed Parthenium hysterophorus L.? Proceedings $14^{\text {th }}$ EWRS Symposium, Hamar, Norway, 17-21 June 2007, p. 166.

Channappagoundar, B.B., Panchal, Y.C., Manjunath, S. and Koti, R.V. (1990). Studies on influence of parthenium on sorghum growth under irrigated conditions. Farming Systems. 6, 102-104.

Evans, H.C. (1997). Parthenium hysterophorus L. A Review of its weed status and the possibility of biological control. Bio-control News and Information, 18, 89-98.

Govindappa, M.R., Shankarappa, K.S., Rangaswamy, K.T. and Muniyappa, V. (2005).In vitro evaluation of plant protection chemicals for compatibility with potential bioagent Paecilomyces farinosus of whitefly (Bemisia tabaci), an insect vector of tomato leaf curl virus disease. Environment and Ecology. 23S (Special 3): 517-522.

Ghosh, P.K., Dayal, D., Bandyopadhyay, K.K. and Mohanty, M. (2006). Evaluation of straw and polythene mulch for enhancing productivity of irrigated summer groundnut. Field Crops Research. 99, 76-86.

Gnanavel, I. (2013): Parthenium hysterophorus L.: A Major threat to natural and agro ecosystems in India. Science International. 1, 186-193.

Hochmuth, G.J., Hochmuth, R.C. and Olson, S.M. (2001). Polyethylene mulching for early vegetable production in north Florida. University of Florida/Institute of Food and Agricultural Sciences (UF/IFAS), Florida A \& M University Cooperative Extension Programme. http:/edis.ifas.ufl.edu

Hudu, A.I., Futuless, K.N. and Gworgwor, N.A. (2002). Effects of mulching intensity on the growth and yield of irrigated tomato (Lycopersicon esculentum Mill.) and weed infestation in semi-arid zone of Nigeria. Journal of Sustainable Agriculture 21, 37-45.

http://www.agridept.gov.lk/index.php/en/crop-recommendations/988

Jayasuriya, A.H.M. (1999). Weed alert. Parthenium hysterophorus in Sri Lanka. Plant Protection Newsletter 3(2). Postgraduate Institute of Agriculture, University of Peradeniya. ISSN 139 1- 345X.

Javaid, A., Shafique, S. and Shafique, S. (2010). Seasonal pattern of seed dormancy in Parthenium hysterophorus L. Pak. J. Bot., 42, 497-503

Kanchan, S.D. (1975). Growth inhibitors from Parthenium hysterophorus L. Current Science, 44, 358-359. 
Kanchan, S.D. and Jayachandra (1980). Allelopathic effect of Parthenium hysterophorus L. Part II. Leaching of inhibitors from aerial vegetative parts. Plant and Soil, 55, 61-6.

Khan, H., Khan, B. M., Hassan,G. and Muhammad, A. K. (2013). Socio-economic impacts of parthenium (Parthenium hysterophorus L.) in peshawar valley, Pakistan. Pak. J. Weed Sci. Res., 19(3), 275-293.

Khosla, S.N. and Sobti, S.N. (1981): Effective control of Parthenium hysterophorus L. Pesticides, 15, 18-19.

Liu, Y., Shen, Y., Yang, S., Li, S. and Chen, F. (2011).Effect of mulch and irrigation practices on soil water, soil temperature and the grain yield of maize in Loess Plateau, China. African Journal of Agricultural Research. 6(10), 2175-2182.

Marambe, B, Jayaskera, S., Samarasinghe, J.D. and Wimal Kumara, P. (2011). National Priorities in Plant Protection Research - Strategic Approach 2011-2013. A Publication of the National Plant Protection Committee, Sri Lanka Council for Agricultural Research Policy. 38 pp.

Marambe, B., Wijesundera, S., Tennakoon, K., Pindeniya, P. and Jayasinghe, C. (2002). Growth and development of Cuscuta chinensis Lam. and its impact on selected crops. Weed Biology and Management 2: 79-83.

Marambe, B., Bambaradeniya, C., Pushpa Kumara, D.K. and Pallewatta, N. (2001). Human dimensions of invasive alien species in Sri Lanka. Pp 135-142. In: McNeely J.A. (Ed). The Great Reshuffling; Human Dimensions of Invasive Alien Species, IUCN, Gland, Switzerland and Cambridge, UK.

Marambe, B. and Sangakkara, U.R. (1997). Effect of EM on weed populations, weed growth and tomato production in Kyusei nature farming. pp 211-216.In: Parr J.F. and Hornick, S.B. (Eds). Proceedings of $4^{\text {th }}$ Conference on Kyusei Nature Farming 19-21 June 1995, Paris, France.

Marambe, B. (1996). Physiology of vegetative reproduction strategy of purple nutsedge (Cyperus rotundus L). Sri Lankan Journal of Agricultural Science 33, 43-57.

Monaco, T.J., Garyson, A.S. and Sanders, D.C.(1981). Influence of four weed species on the growth, yield, and quantity of direct-seeded tomatoes (Lycopersicon esculentum). Weed Sci. 29, 394-397.

Navie, S.C., McFadyen, R.C., Panetta, F.D. and Adkins, S.W. (1996). The Biology of Australian weed Parthenium hysterophorus L. Plant Protection Quarterly, 11, 76-88.

Navie, S.C., Panetta, F.D., McFadyen, R.E. and Adkins, S.W. (1998). Behavior of buried and surface sown seeds of Parthenium hysterophorus L. Weed Research 38, 335-341.

Olasantan, F.O. (2000). Effect of nitrogen rate on okra and tomato in gliricidia alley cropping system in South-western Nigeria. Tropical Agricultural Research and Extension 3, $110-114$. 
Opara-Nadi, O.A. (1993). Effect of elephant grass and plastic mulch on soil properties and cowpea yield. pp 351-360.In: Mulongoy, K. and Merckx. R. (Eds). Soil Organic Matter Dynamics and Sustainability of Tropical Agriculture. John Wiley and Sons, New York, U.S.A.

Rajapakse, R., Chandrasena, N., Marambe, B. and Amarasinghe L. (2012). Planning for effective weed management: Lessons from Sri Lanka. Pakistan Journal of Weed Science Research 18, 843-853.

Ranwala, S.1, Marambe, B., Wijesundara, S., Silva, P., Weerakoon, D.1., Atapattu, N., Gunawardena, J., Manawadu, L. and Gamage, G. (2011). Post-entry risk assessment of invasive alien flora in Sri Lanka - present status, gap analysis, and the most troublesome alien invaders. Pakistan Journal of Weed Science Research 18, 863-871.

Silva, P.S.L., Cunha, T.M.S., Oliveira, R.C., Silva, K.M.B. and Oliveira, O.F. (2009). Weed control via intercropping with gliricidia. II. Corn crop. Planta Daninha. 27, 105-112.

Sukhada, D.K. and Jayachandra (1979). Allelopathic effects of Parthenium hysteroporus L. I. Exudation of inhabitants through roots, Plant and Soil, 53, 27-35.

Seneviratne, S.N. de S., Sivakadacham, B. and Jayanandarajah, P. (1984). Seeds, Soils and Weeds as Determinants of the Health Status of Cultivated Crops. Annual Res. Conf. Cereals and Grain Legumes Division, Dept. Agric. pp 1 -3.

Shabbir, A. and Bajwa, R. (2006).Distribution of parthenium weed (Parthenium hysterophorus L.), an alien invasive weed species threatening the biodiversity of Islamabad. Weed Biology and Management. 6, 89-95.

Tamado, T, Ohlander, L. and Milberg, P. (2002). Interference by the weed Parthenium hysterophorus L with grain sorghum: influence of weed density and duration of competition. International Journal of Pest Management, 48, 183-188.

Tiang, G. and Kang, B.T. (1994). Evaluation of Gliricidia sepium prunings for phytotoxicity on maize and cowpea seedlings. Agrofor. Syst. 26, 249-254.

Towers, G.H., Mitcheu, N., Rodriguez, J.C., Bennett, E. and Subba Rao, P.V. (1977). Biology and chemistry of Parthenium hysterophorus L a problematic weed in India. J. Scientific and Industrial Research. 36, 672-684. 